\title{
Detection, characterization, and antibiogram of extended-spectrum beta-lactamase Escherichia coli isolated from bovine milk samples in West Bengal, India
}

Kunal Batabyal ${ }^{1}$, Abhiroop Banerjee ${ }^{1}$, Susmita Pal ${ }^{1}$, Samir Dey ${ }^{1}$, Siddhartha Narayan Joardar ${ }^{1}$, Indranil Samanta ${ }^{1}$, Devi Prasad Isore ${ }^{1}$ and Abhishek Dharm Singh ${ }^{2}$

1. Department of Veterinary Microbiology, Faculty of Veterinary and Animal Sciences, West Bengal University of Animal and Fishery Sciences, Kolkata, West Bengal, India; 2. Department of Veterinary Public Health, F/VAS, West Bengal University of Animal and Fishery Sciences, Kolkata, West Bengal, India. Corresponding author: Kunal Batabyal, e-mail: drkb.micro@gmail.com

Co-authors: AB: abdocarp@gmail.com, SP: sushvet60@gmail.com, SD: drsamirdey@gmail.com,

SNJ: joardar69@gmail.com, IS: isamanta76@gmail.com, DPI: deviprasadisore@gmail.com, ADS: abhivph@gmail.com Received: 23-07-2018, Accepted: 07-09-2018, Published online: 16-10-2018

doi: 10.14202/vetworld.2018.1423-1427 How to cite this article: Batabyal K, Banerjee A, Pal S, Dey S, Joardar SN, Samanta I, Isore DP, Singh AD (2018) Detection, characterization, and antibiogram of extended-spectrum beta-lactamase Escherichia coli isolated from bovine milk samples in West Bengal, India, Veterinary World, 11(10): 1423-1427.

\begin{abstract}
Background: Milk is considered as complete food and an important part of human diet throughout the world including India. Bacterial contamination of milk such as Escherichia coli due to unhygienic condition and poor udder health can cause infections, especially in infants and elders or in immunocompromised persons. Possession of antimicrobial resistance genes by commensal bacteria present in milk makes the issue more serious.

Aim: The study was aimed to isolate and characterize extended-spectrum beta-lactamase (ESBL)-producing E. coli from milk samples collected from different parts of West Bengal, India, to assess the potential risk associated with the food.

Materials and Methods: Around 182 milk samples were collected from apparently healthy cows reared by organized dairy farms in West Bengal. E. coli was isolated from collected samples as per standard methods followed by serotyping. The detection of ESBL-producing E. coli was done both phenotypically and genotypically by detecting the presence of bla $a_{\mathrm{CTX}-\mathrm{M}}$ gene. Antibiogram of the ESBL-positive isolates was done using common 12 antibiotics by disc diffusion method.

Results: A total of $22(12.1 \%)$ samples were found to be positive for E. coli in this study. Different serotypes such as O11, O20, O22, O34, O35, O128, O149, and UT were isolated from the collected samples. 12 (54.5\%) E. coli strains showed the capability of producing ESBL, both phenotypically and genotypically with the presence of $b l a_{\text {СтХ-м }}$ gene. Antibiogram of these ESBL-positive isolates revealed the drugs such as colistin (100\%), levofloxacin (83.33\%), and imipenem (66.67\%) to be highly sensitive against this pathogen but drugs such as cefotaxime (100\%), ceftazidime (91.67\%), amoxicillin/clavulanic acid $(83.33 \%)$, tetracycline $(75.00 \%)$, and gentamicin $(58.33 \%)$ to be very much resistant.
\end{abstract}

Conclusion: More than $50 \%$ of the $E$. coli strains prevalent in the bovine milk samples were positive for ESBL production and are resistant to most of the common antimicrobials which may be alarming for human health.

Keywords: antibiogram, bla ${ }_{\text {СтХ-м}}$, bovine milk, extended-spectrum beta-lactamase, Escherichia coli.

\section{Introduction}

India is one of the largest milk producing countries in the world with dairy industry playing an important role in the rural economy [1] generating huge self-employment. Bovine milk is generally considered to be a good source of protein and vitamins to human beings, particularly to the infants. However, due to faulty handling and storage of milk and poor management of the animal, milk may get spoiled due to rapid multiplication of bacteria due to milk's high nutritive value [2]. Escherichia coli is one dreadful pathogen, especially the "enterohemorrhagic E. coli"

Copyright: Batabyal, et al. Open Access. This article is distributed under the terms of the Creative Commons Attribution 4.0 International License (http://creativecommons.org/licenses/ by/4.0/), which permits unrestricted use, distribution, and reproduction in any medium, provided you give appropriate credit to the original author(s) and the source, provide a link to the Creative Commons license, and indicate if changes were made. The Creative Commons Public Domain Dedication waiver (http:// creativecommons.org/publicdomain/zero/1.0/) applies to the data made available in this article, unless otherwise stated. strains, causing infection through milk which has a great effect on human health $[3,4]$.

The prevalence of extended-spectrum beta-lactamase (ESBL)-producing $E$. coli is increasing in the globe including India. These pathogens pose a major challenge for the treatment of general infections and cause a problem with the extensive use of second- or third-generation antibiotics for the treatment of bacterial infections [5]. ESBL E. coli is mostly insensitive to lots of commonly used antibiotics causing an increase in the use of last-resort antimicrobial drugs (i.e., carbapenems) during treatment. Again, E. coli strains carrying the resistance genes can easily transfer those genes to other pathogens leading to the spread of drug resistance [6]. Hence, the presence of ESBL-producing E. coli in the food processing chain or in the food of our daily consumption which is possibly coming from these healthy farm animals is the fact which has to be appropriately studied. 
The present study was aimed for the detection and characterization of ESBL-producing $E$. coli from raw milk samples (by detecting bla $a_{\text {Стх-М }}$ gene in the isolates) from different dairy farms followed by further characterization and to know their antibiotic resistance patterns in vitro.

\section{Materials and Methods}

\section{Ethical approval}

As per the guidelines of the Committee for the Purpose of Control and Supervision of Experiments on Animals, this study does not require any ethical approval from the University Animal Ethics Committee.

\section{Collection of samples}

Bovine milk samples $(n=182)$ were collected from different unorganized dairy farms of West Bengal aseptically in sterile plastic containers (Table-1) during the period of April-June, 2018. Milk samples were taken at $15 \mathrm{ml}$ (approximately) in sterile plastic containers directly from the teats of the cows. The cows were selected on the basis of the history of illness/ with decreased milk yield. The samples containers were kept in sample flask under ice and cooling pad cover and were transported through shortest route (for maximum 5-6 $\mathrm{h}$ approximately) to the Department of Veterinary Microbiology, Mohanpur, Nadia, for further study. All the collected samples were studied on the same day of receiving at the laboratory.

\section{Isolation and characterization of $E$. coli}

The collected milk samples were enriched adding sterile nutrient broth at $37^{\circ} \mathrm{C}$ for $6-8 \mathrm{~h}$ followed by streaking on to sterile MacConkey's agar (HiMedia, India) plates. The plates were incubated aerobically at $37^{\circ} \mathrm{C}$ for $10-12 \mathrm{~h}$. The tentative pinkish single colonies (i.e., lactose fermenting) were selected for selective isolation by further streaking on sterile Eosin Methylene Blue (EMB) agar (HiMedia, India) plates followed by $10-12 \mathrm{~h}$ incubation again at $37^{\circ} \mathrm{C}$. The single colonies showing characteristic greenish "metallic sheen" were picked up and were stored using sterile nutrient agar (HiMedia, India) slants for further morphological study by Gram's staining method and biochemical characterization with tests such as indole, methyl red, citrate utilization, Voges-Proskauer, catalase, and nitrate reduction $[7,8]$. All positive isolates showing typically to be $E$. coli were further confirmed for ESBL positivity later.

\section{Serotyping of the $E$. coli isolates}

All positive E. coli isolates were sent to the National Salmonella and Escherichia Centre,
Central Research Institute, Kasauli, Himachal Pradesh, India, for serotyping. All E. coli strains were subcultured in small sterile glass vials and were properly packed in hardboard box under cotton cover followed by sending to the NSEC, Kasauli, by registered post.

\section{Phenotypic detection of ESBL production in $E$. coli isolates}

Phenotypic detection of the presence of ESBL in $E$. coli isolates was done in vitro by disc diffusion method [9] using both cefotaxime $(30 \mu \mathrm{g})$ and ceftazidime disks $(30 \mu \mathrm{g})$ with and without clavulanate $(10 \mu \mathrm{g})$ as per the CLSI methods by Patel et al. [10]. A difference of $>5 \mathrm{~mm}$ between the zone diameters of each disk and their respective clavulanate disk is measured to phenotypically confirm the ESBL production by the $E$. coli isolates under study [10].

Molecular detection of ESBL production in $E$. coli isolates by polymerase chain reaction (PCR)

\section{Bacterial culture lysate preparation}

Selective E. coli strains were inoculated into nutrient broth (HiMedia, India) followed by $18 \mathrm{~h}$ incubation at $37^{\circ} \mathrm{C} .1 \mathrm{ml}$ of young broth culture of each sample was taken in a sterile $1.5 \mathrm{ml}$ microcentrifuge tube (Tarsons, India) followed by centrifugation at $6000 \mathrm{rpm}$ for $5 \mathrm{~min}$ [11]. The obtained pellet was washed 3 times with TE buffer and was suspended again in TE buffer $(1 \mathrm{ml})$. The microcentrifuge tube with culture was then boiled in water for $10 \mathrm{~min}$ followed by chilling in ice. Again each tube was centrifuged at $5000 \mathrm{rpm}$ for $5 \mathrm{~min}$ followed by removal of cell debris and the supernatant with crude DNA was collected and stored at $-20^{\circ} \mathrm{C}$ for further use as a template in PCR [11].

Detection of bla ${ }_{\text {Стх-м }}$ gene $(540 \mathrm{bp}$ ) in E. coli isolates

All phenotypically ESBL-positive E. coli isolates were considered for confirmation by PCR detection of the $b l a_{\text {СТХ-м }}$ gene in them as per the protocol followed by Weill et al. [12] with slight modifications. All standard reagents and primers (GCC Biotech, India) were used in this process. Amplification reaction mixture containing $3 \mu 1$ DNA templates, 50 pmol the primer set [540 bp] (forward ${ }_{\text {CTX-M }}$-F 5'-CAATGTGCAGCACCAGTAA-3' and reverse ${ }_{\text {СтX-м }}$-R 5'-CGCGATATCATTGGTGGTG-3'), 1 U GoTaq DNA polymerase (Promega, USA), $200 \mathrm{mM}$ deoxynucleoside triphosphate, $10 \%$ dimethyl sulfoxide, and $2 \mathrm{mM} \mathrm{MgCl}{ }_{2}$ was prepared in a $25 \mu 1$ reaction mixture and used in PCR amplification conducted in a

Table-1: Details of milk sample collection from different districts of West Bengal, India.

\begin{tabular}{lcc}
\hline Name of the districts & Number of dairy farms covered & Total number collected samples \\
\hline Purba Bardhaman & 04 & 32 \\
Paschim Bardhaman & 05 & 47 \\
Nadia & 03 & 29 \\
Hooghly & 11 & 74 \\
Total & 23 & 182 \\
\hline
\end{tabular}


thermocycler (Eppendorf, Germany). The PCR amplification was done in the following cycle condition with an initial denaturation at $94^{\circ} \mathrm{C}$ for $10 \mathrm{~min}$, followed by 30 cycles of denaturation at $94^{\circ} \mathrm{C}$ for $30 \mathrm{~s}$, annealing at $53^{\circ} \mathrm{C}$ for $30 \mathrm{~s}$, and elongation at $72^{\circ} \mathrm{C}$ for $60 \mathrm{~s}$ with a $10 \mathrm{~min}$ final extension period at $72^{\circ} \mathrm{C}$. The amplified PCR products were loaded onto a $1.5 \% \mathrm{w} / \mathrm{v}$ agarose gel (SRL, India), with ethidium bromide $(0.5 \mu \mathrm{g} / \mathrm{ml})$ (SRL, India) followed by agarose gel electrophoresis and were visualized by gel documentation system (UVP, $\mathrm{UK})$. One ESBL-producing E. coli strain (O2) which is the departmental isolate and one Pseudomonas aeruginosa (ATCC 27853) were used as positive and negative controls in PCR assays.

\section{In vitro antibiotic sensitivity test of ESBL E. coli isolates}

Antibiogram of the ESBL-positive E. coli isolates was performed using 12 antimicrobials, i.e., amikacin, amoxicillin/clavulanic acid, azithromycin, colistin, cotrimoxazole, cefotaxime, ceftazidime, gentamicin, imipenem, levofloxacin, piperacillin-tazobactam, and tetracycline by Kirby-Bauer disc diffusion method [9]. Young broth cultures of all the ESBL-positive isolates were produced for the test. Separate and sterile Mueller-Hinton agar (HiMedia, India) plates were used for uniform spreading of each broth culture using sterile L-spreader, and standard discs (HiMedia, India) were placed with sterile forceps. All the plates were incubated at $37^{\circ} \mathrm{C}$ for 10-12 $\mathrm{h}$, and the results were interpreted by measuring the inhibition zone diameter and comparing those with the standard chart [10].

\section{Results}

Out of 182 bovine milk samples tested, $22(12.08 \%)$ samples were found to be identified as E. coli in this study. All the positive isolates showed typical characteristics during cultural, i.e., produced typical "metallic sheen" when grown on EMB agar plates (Figure-1) and morphological examinations (pink rods after Gram's staining). All showed typical results during their biochemical characterization, i.e., positive to indole, methyl red, catalase, and nitrate reduction whereas negative to VP and citrate utilization.

Serotyping of all $22 \mathrm{E}$. coli isolates was done at the National Salmonella and Escherichia Centre, Central Research Institute, Kasauli, HP, India, to get the following 8 different serotypes, i.e., O11, O20, O22, O34, O35, O128, O149, and UT (Table-2).

During ESBL detection, a total of $12(54.54 \%)$ $E$. coli isolates were found to be phenotypically positive as ESBL producers by double disc method in this study. All phenotypically ESBL-positive $E$. coli isolates were detected to have the $b l a_{\text {CTX-M }}$ gene $(540 \mathrm{bp})$ by PCR (Figure-2). The ESBL-producing strains belonged to O11[2 nos.], O20 [4 nos.], O22 [5 nos.], and 0128 [1 no.]. Samples from Purba Bardhaman

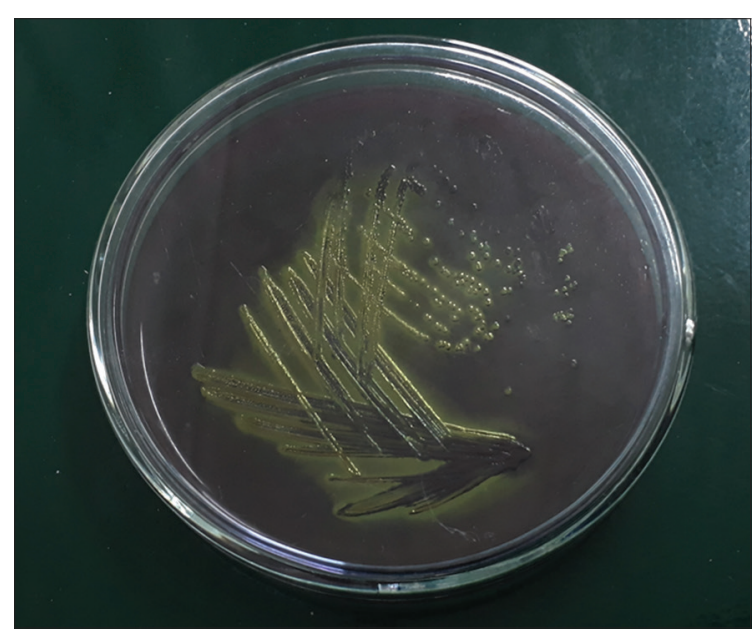

Figure-1: Characteristic "metallic sheen" produced by positive Escherichia coli isolated from bovine milk samples on Eosin Methylene Blue agar plate.

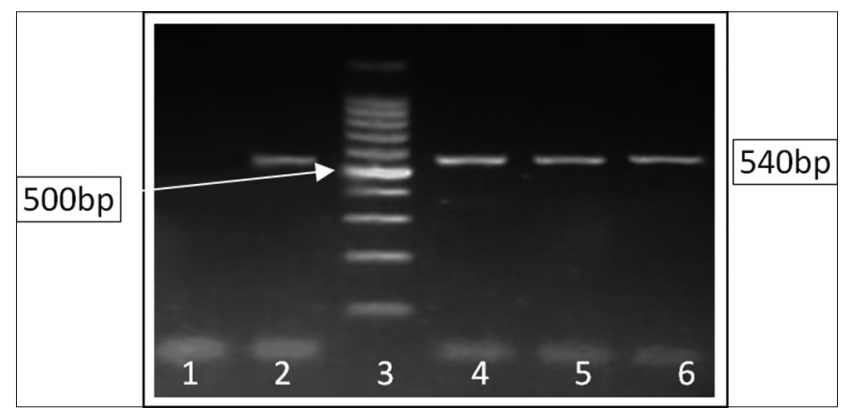

Figure-2: Polymerase chain reaction detection of bla стх-м $_{1}$ gene (540 bp) in extended-spectrum beta-lactamaseproducing Escherichia coli strains isolated from bovine milk samples in West Bengal, India. Lane 1: Negative control, Lane 2: Positive control, Lane 3: 100 bp ladder, Lanes 4-6: Test samples.

Table-2: Frequency of $E$. coli serotypes isolated from bovine milk samples.

\begin{tabular}{lcc}
\hline SI. No. & E. coli serotypes & $\begin{array}{c}\text { Frequency of } \\
\text { prevalence (\%) }\end{array}$ \\
\hline 1 & 011 & $3(13.63)$ \\
2 & $\mathrm{O} 20$ & $7(31.82)$ \\
3 & $\mathrm{O} 149$ & $3(13.63)$ \\
4 & $\mathrm{O} 22$ & $5(22.72)$ \\
5 & $\mathrm{O} 35$ & $1(4.55)$ \\
6 & $\mathrm{O} 34$ & $1(4.55)$ \\
7 & O128 & $1(4.55)$ \\
8 & UT & $1(4.55)$ \\
Total & & $22(100.00)$ \\
\hline
\end{tabular}

E. coli=Escherichia coli

district showed the highest positivity in comparison to other districts (Table-3).

In vitro, antibiotic sensitivity assay of the ESBLpositive E. coli isolates showed high-level resistance to cefotaxime, ceftazidime, amoxicillin-clavulanic acid, tetracycline, gentamicin, amikacin, etc. (with the range of $60-100 \%)$. Piperacillin-tazobactam (83.33\%) was detected to be intermediately sensitive to these isolates (Table-4), and drugs such as colistin, levofloxacin, and imipenem were found to be sensitive against these pathogens. 
Table-3: District-wise Distribution of $E$. coli isolates with ESBL positivity.

\begin{tabular}{lccc}
\hline $\begin{array}{l}\text { Name of the } \\
\text { Districts }\end{array}$ & $\begin{array}{c}\text { Number of samples } \\
\text { studied }\end{array}$ & $\begin{array}{c}\text { Number of E. coli strains } \\
\text { isolated (\%) }\end{array}$ & $\begin{array}{c}\text { ESBL positivity in E. coli } \\
\text { strains }\end{array}$ \\
\hline Purba Bardhaman & 32 & $6(18.75)$ & 5 \\
Paschim Bardhaman & 47 & $7(14.89)$ & 4 \\
Nadia & 29 & $2(6.90)$ & 1 \\
Hooghly & 74 & $7(9.46)$ & 2 \\
Total & 182 & $22(12.08)$ & 12 \\
\hline
\end{tabular}

E. coli=Escherichia coli, $\mathrm{ESBL}=$ Extended-spectrum beta-lactamase

Table-4: Antibiogram of 12 ESBL-producing E. coli strains isolated from bovine milk samples in West Bengal, India.

\begin{tabular}{|c|c|c|c|c|}
\hline \multirow[t]{2}{*}{ SI. No. } & \multirow[t]{2}{*}{ Antimicrobials (Conc. in $\mu \mathrm{g}$ ) } & \multicolumn{2}{|c|}{ Isolates sensitive Isolates intermediately sensitive } & \multirow{2}{*}{$\frac{\text { Isolates resistant }}{\mathrm{n}(\%)}$} \\
\hline & & n (\%) & n (\%) & \\
\hline 1. & Amikacin (30) & $2(16.67)$ & $3(25.00)$ & $7(58.33)$ \\
\hline 2. & Amoxicillin/Clavulanic acid (20/10) & $2(16.67)$ & $0(0)$ & $10(83.33)$ \\
\hline 3. & Colistin (10) & $12(100)$ & $0(0)$ & $0(0)$ \\
\hline 4. & Cotrimoxazole (25) & $5(41.67)$ & $4(33.33)$ & $3(25.00)$ \\
\hline 5. & Cefotaxime (30) & $0(0)$ & $0(0)$ & $12(100)$ \\
\hline 6. & Ceftazidime (30) & $0(0)$ & $1(8.33)$ & $11(91.67)$ \\
\hline 7. & Imipenem (10) & $8(66.67)$ & $4(33.33)$ & $0(0)$ \\
\hline 8. & Gentamicin (10) & $0(0)$ & $5(41.67)$ & $7(58.33)$ \\
\hline 9. & Levofloxacin (5) & $10(83.33)$ & $2(16.67)$ & $0(0)$ \\
\hline 10. & Pipercillin-Tazobactam (100/10) & $2(16.67)$ & $10(83.33)$ & $0(0)$ \\
\hline 11. & Azithromycin (30) & $4(33.33)$ & $3(25.00)$ & $5(41.67)$ \\
\hline 12. & Tetracycline (30) & $2(16.67)$ & $1(8.33)$ & $9(75.00)$ \\
\hline
\end{tabular}

$\mathrm{ESBL}=$ Extended-spectrum beta-lactamase, E. coli=Escherichia coli

\section{Discussion}

Approximately $12 \%$ of the total milk samples screened were found to yield $E$. coli isolates in this study which were also supported by Kamaruzzaman [13], Badri et al. [14], Geser et al. [15], and Ali et al. [16] who also reported 12.22-13.7\% $E$. coli positivity in the bovine milk samples during their study. All positive E. coli isolates showed typical cultural, morphological, and biochemical nature in this study which was also supported by Carter and Wise [7], Samanta [17], and Quinn et al. [8].

The serotypes reported by the National Salmonella and Escherichia Centre, Central Research Institute, Kasauli, were also supported by Osman et al. [18] who detected E. coli serogroups O26, O86, O111, and 0127 from cattle milk in their study. Al-Zogibi et al. [19] reported the prevalence of $E$. coli serogroups, namely O22, O111, O113, and O172, from bovine milk samples in their study which also supports the current findings.

Approximately, 54.54\% E. coli isolates were both phenotypically and genotypically positive to produce ESBL in this study which was also supported by Geser et al. [15] and Ibrahim et al. [20]. Kamaruzzaman [13] reported a high prevalence of ESBL-producing $E$. coli in milk (66.7\%) followed by farm environment (27.8\%) and cattle (5.5\%) in his work. Ali et al. [16] reported 36 (23.53\%) and Badri et al. [14] reported 29.3\% ESBL-positive E. coli strains from bovine milk samples which may be of great concern as these pathogens may be carried out to the human consumers as well as calves leading to the spread of the antibiotic-resistant pathogens over human and animal population. Sharma et al. [21] also reported ESBL-positive $E$. coli serotypes in their study, matching the current findings.

The high level of antibiotic resistance as shown in this report was also reported earlier by Kamaruzzaman [13], Ibrahim et al. [20], and Hinthong et al. [22]. Ali et al. [16] also found resistance against drugs such as ampicillin (86.11\%), amoxicillin-clavulanic acid (63.89\%), cefotaxime (100\%), ceftazidime $(66.67 \%)$, tetracycline $(72.22 \%)$, and gentamicin $(61.11 \%)$ by ESBL E. coli pathogens in their study. Faruk et al. [23] reported that ampicillin, cefotaxime, ceftazidime, and cefuroxime (all 100\%) and tetracycline $(93.54 \%)$ were highly resistant but imipenem $(100 \%)$ to be highly sensitive to the ESBL E. coli strains isolated from cattle in their study which almost matches with the current findings.

\section{Conclusion}

The drug-resistant ESBL gene is significantly present in approximately $55 \%$ of the $E$. coli strains isolated from cattle milk samples which may be of great health concern for human beings. This drug resistance can easily be transferred between closely related pathogens in vivo which may result in risky and fatal health hazards due to unsuccessful treatment with common antimicrobials. Hence, proper care should be taken to combat these dreadful pathogens.

\section{Author's Contributions}

$\mathrm{KB}$ and SD designed the study. AB and ADS collected the samples. KB, AB, and SP carried out the 
experiment. SNJ, SD, and IS analyzed the data. DPI, $\mathrm{KB}$, and SD drafted the article. SNJ and IS revised the article. All authors read and approved the final manuscript.

\section{Acknowledgments}

The authors thank the University Authorities and the Faculties of the Department of Veterinary Microbiology, West Bengal University of Animal and Fishery Sciences, West Bengal, India, for providing necessary funds [ICAR Development Grant 201718 ( $2^{\text {nd }}$ Installment $)$, Order no. VCS/WBUAFS/118(Pt-1)/09(11)/10, dated. 24.11.17], research facilities, and support for this study. They are also thankful to the farm owners, dairy farmers, and local veterinary doctors of the concerned districts of West Bengal, India, for their technical and field support.

\section{Competing Interests} interests.

The authors declare that they have no competing

\section{References}

1. A Study of India's Dairy Sector 2017: The World's Largest Producer and Consumer - Research and Markets. Available from: https://www.businesswire.com/news/ home/20180102005671/en/Study-Indias-Dairy-Sector2017-Worlds-Largest. Last accessed on 18-07-2018.

2. Oliver, S.P., Jayarao, B.M. and Almeida, R.A. (2005) Foodborne pathogens in milk and the dairy farm environment: Food safety and public health implications. Foodborne Pathog. Dis. Summer, 2(2): 115-129.

3. Hickey, C.D., Sheehan, J.J., Wilkinson, M.G. and Auty, M.A.E. (2015) Growth and location of bacterial colonies within dairy foods using microscopy techniques: A review. Front. Microbiol., 6: 99

4. Nguyen, Y. and Sperandio, V. (2012) Enterohemorrhagic E. coli (EHEC) pathogenesis. Front. Cell. Infect. Microbiol., 2(90): 1-7.

5. Tenover, F.C., Mohammed, M.J., Gorton, T.S. and Dembek, Z.F. (1999) Detection and reporting of organisms producing extended spectrum-beta-lactamases: Survey of laboratories in Connecticut. J. Clin. Microbiol., 37(12): 4065-4070.

6. Hu, Y., Yang, X., Li, J., Lv, N., Liu, F., Wu, J., Lin, I.Y.C., $\mathrm{Wu}$, N., Weimer, B.C., Gao, G.F., Liu, Y. and Zhu, B. (2016) The transfer network of bacterial mobile resistome connecting animal and human microbiome. Appl. Environ. Microbiol., 82(22): 66726681.

7. Carter, G.R. and Wise, D.J. (2004) Essentials of Veterinary Bacteriology and Mycology. $6^{\text {th }}$ ed. Iowa State Press, Iowa. p129-134.

8. Quinn, P.J., Markey, B.K., Leonard, F.C., Fitz, P.E.S., Fanning, S. and Hartigan, P.J. (2011) Veterinary Microbiology and Microbial Diseases. $2^{\text {nd }}$ ed. Blackwell Publishing Ltd., Oxford. p266-273.

9. Bauer, A.W., Kirby, W.M., Sherrris, J.C. and Turck, M. (1966) Antibiotic susceptibility testing by a standardized single disk method. Am. J. Clin. Pathol., 45(4): 493-496.

10. Patel, J.B., Cockerill, F.R., Bradford, P.A., Eliopoulos, G.M., Hindler, J.A., Jenkins, S.G., Lewis, J.S., Limbago, B., Miller, L.A., Nicolau, D.P., Powell, M., Swenson, J.M.,
Traczewski, M.M., Turnidge, J.D., Weinstein, M.P. and Zimmer, B.L. (2015) Clinical and Laboratory Standard Institute: Performance Standards for Antimicrobial Susceptibility Testing; Twenty-Fifth Informational Supplement. CLSI Document $\mathrm{M}_{100}-\mathrm{S}_{25}$. CLSI, Wayne, Pa, USA. p1-240.

11. Salehi, T.Z., Mahzounieh, M. and Saeedzadeh, A. (2005) Detection of invA gene in isolated salmonella from broilers by PCR method. Int. J. Poult. Sci., 4(8): 557-559.

12. Weill, F., Claude, J., Demartin, C.S. and Grimont, P. (2004) Characterization of ESBL (CTX-M-15) producing strains of Salmonella enterica isolated in France and Senegal. FEMS Microbiol. Lett., 238(2): 353-358.

13. Kamaruzzaman, E.A. (2015) Occurrence of ExtendedSpectrum Beta-Lactamase Producing Escherichia coli in Dairy Cattle, Farm Environment and Milk. Masters Degree Thesis Submitted in the University of Putra, Malaysia.

14. Badri, A.M., Ibrahim, I.T., Mohamed, S.G., Garbi, M.I., Kabbashi, A.S. and Arbab, M.H. (2017) Prevalence of extended-spectrum beta-lactamase (ESBL) producing Escherichia coli and Klebsiella pneumoniae isolated from raw milk samples in Al Jazirah State, Sudan. Mol. Biol., 7(1): 201

15. Geser, N., Stephan, R. and Hachler, H. (2012) Occurrence and characteristics of extended-spectrum beta-lactamase (ESBL) producing Enterobacteriaceae in food-producing animals, minced meat and raw milk. BMC Vet. Res., 8(1): 21.

16. Ali, T., Ur Rahman, S., Zhang, L., Shahid, M., Zhang, S., Liu, G., Gao, J. and Han, B. (2016) ESBLproducing Escherichia coli from cows suffering mastitis in China contain clinical class 1 integrons with CTX-M linked to ISCR1. Front. Microbiol., 7: 1931.

17. Samanta, I. (2013) Enterobacteriaceae. In: Veterinary Bacteriology. Ch. 6. New India Publishing Agency, New Delhi. p119-135.

18. Osman, K.M., Mustafa, A.M., Aly, M.A. and Abd, E.G.S. (2012) Serotypes, virulence genes, and intimin types of Shiga toxin-producing Escherichia coli and enteropathogenic Escherichia coli isolated from mastitic milk relevant to human health in Egypt. Vector Borne Zoonotic Dis., 12(4): 297-305.

19. Al-Zogibi, O.G., Mohamed, M.I., Hessain, A.M., El-Jakee, J.K. and Kabli, S.A. (2015) Molecular and serotyping characterization of Shiga toxogenic Escherichia coli associated with food collected from Saudi Arabia. Saudi J. Biol. Sci., 22(4): 438-442.

20. Ibrahim, D.R., Dodd, C.E.R., Stekel, D.J., Ramsden, S.J. and Hobman, J.L. (2016) Multidrug-resistant, extended spectrum $\beta$-lactamase (ESBL)-producing Escherichia coli isolated from a dairy farm. FEMS Microbiol. Eco., 92(4): fiw013.

21. Sharma, S., Kaur, N., Malhotra, S., Madan, P., Ahmad, W. and Hans, C. (2016) Serotyping and antimicrobial susceptibility pattern of Escherichia coli isolates from urinary tract infections in pediatric population in a tertiary care hospital. J. Pathog., 2016(2548517): 4.

22. Hinthong, W., Pumipuntu, N., Santajit, S., Kulpeanprasit, S., Buranasinsup, S., Sookrung, N., Chaicumpa, W., Pisinee, A.P. and Indrawattana, N. (2017) Detection and drug resistance profile of Escherichia coli from subclinical mastitis cows and water supply in dairy farms in Saraburi Province, Thailand. Peer J., 5: e3431.

23. Faruk, P., Hulya, T., Dilek, O. and Hakan, Y. (2016) Molecular characterization of ESBL-producing Escherichia coli isolated from healthy cattle and sheep. Acta Vet. Beogr., 66(4): 520-533. 